\title{
RELAÇÕES URBANO-REGIONAIS DO RECORTE ESPACIAL AGLOMERAÇÃO METROPOLITANA DE CURITIBA, PONTA GROSSA E PARANAGUÁ'.
}

\author{
Rosa Moura ${ }^{2}$
}

A reflexão acerca da concentração urbana vem trazendo ao debate conceitos que se diferenciam por pequenas nuanças. Convergm no entendimento de que aumentam configurações sobre mais de um município, estado ou país, centradas em um pólo ou multipolarizadas, desencadeando intensos fluxos de relações internamente e com outros espaços. No âmbito metropolitano, os conceitos incorporam a natureza complexa e multidimensional das grandes metrópoles e avançam na percepção de que as dinâmicas urbanas contemporâneas engendram espaços que transcendem concepções restritas de cidade ou aglomeração. Outros conceitos contemplam configurações de menor escala, porém também complexas, articulando cidades em morfologias dispersas. No Paraná, estudos apontam arranjos espaciais complexos, como os conformados pela aglomeração metropolitana de Curitiba / aglomeração descontínua de Ponta Grossa / ocupação contínua do litoral paranaense; o formado pelas aglomerações de Londrina, Maringá e outras centralidades satélites, no norte do Paraná; e o do Oeste do Estado, tomando Cascavel como o vértice de dois eixos de intensa atividade, para a aglomeração urbana internacional de Foz do Iguaçu e Guaíra. Tais arranjos refletem a persistência da concentração espacial da atividade econômica, porém sob conexões geográficas, mais complexas e mais dinâmicas, que se estabelecem a partir da nova divisão social e territorial do trabalho, e que, a despeito de aparentemente contínuas, refletem articulações econômico-sociais desiguais entre os vários municípios, resultando menos em semelhanças e mais heterogeneidades em seu interior. Essas considerações orientaram a escolha do objeto de pesquisa proposto - o recorte que envolve a aglomeração metropolitana de Curitiba, Ponta Grossa e Paranaguá -, que buscará colocar em discussão conceitos; organizar indicadores que revelem continuidades e descontinuidades, articulações e desarticulações, relações verticais e horizontais; e definir a extensão - se é que é possível ser capturada - desse singular arranjo espacial.

PALAVRAS-CHAVE: aglomeração urbana; concentração; metropolização; região metropolitana de Curitiba.

\footnotetext{
${ }^{1}$ Orientadora: Profa. Dra. Olga C. F. Firkowski

2 Doutoranda em Geografia (UFPR) - e-mail: rmoura@pr.gov.br
} 